\title{
A Role for Transforming Growth Factor $\alpha$ as an Inducer of Astrogliosis
}

\author{
Alexander G. Rabchevsky, Juno M. Weinitz, Muriel Coulpier, Christiane Fages, Marina Tinel, and \\ Marie-Pierre Junier \\ Institut National de la Santé et de la Recherche Médicale Unité 421, Faculté de Médecine, U421 Créteil, France
}

\begin{abstract}
TGF $\alpha$ is a member of the epidermal growth factor (EGF) family with which it shares the same receptor, the EGF receptor (EGFR). Synthesis of TGF $\alpha$ and EGFR in reactive astrocytes developing after CNS insults is associated with the differentiative and mitogenic effects of TGF $\alpha$ on cultured astrocytes. This suggests a role for TGF $\alpha$ in the development of astrogliosis. We evaluated this hypothesis using transgenic mice bearing the human TGF $\alpha$ cDNA under the control of the zinc-inducible metallothionein promoter. Expression levels of glial fibrillary acidic protein (GFAP) and vimentin and morphological features of astrocytes were used as indices of astroglial reactivity in adult transgenic versus wild-type mice provided with $\mathrm{ZnCl}_{2}$ in their water for 3 weeks. In the striatum, the hippocampus, and the cervical spinal cord, the three CNS areas monitored, transgenic mice displayed enhanced GFAP mRNA and protein levels and elevated vimentin protein levels. GFAP-immunoreactive
\end{abstract}

astrocytes exhibited numerous thick processes and hypertrophied somata, which are characteristic aspects of reactive astrocytes. Their number increased additionally in the striatum and the spinal cord, but no astrocytic proliferation was observed using bromodeoxyuridine immunohistochemistry. Neither the morphology nor the number of microglial cells appeared modified. A twofold increase in phosphorylated EGFR was detected in the striatum and was associated with the immunohistochemical detection of numerous GFAP-positive astrocytes bearing the EGFR, suggesting a direct action of TGF $\alpha$ on astrocytes. Altogether, these results demonstrate that enhanced TGF $\alpha$ synthesis is sufficient to trigger astrogliosis throughout the CNS, whereas microglial metabolism is unaffected.

Key words: transgene; astrocytes; EGF receptor; gliosis; microglia; astrocytic reactivity
TGF $\alpha$ is a polypeptide endowed with gliotrophic and neurotrophic activities. A member of the epidermal growth factor (EGF) family, it shares with this factor the EGF receptor (EGFR), which mediates all its known biological actions (Lee et al., 1995). Unlike EGF, present at very low levels in the $\mathrm{CNS}, \mathrm{TGF} \alpha$ is easily detectable in both the developing and adult brain (Kaser et al., 1992; Lazar and Blum, 1992; Kornblum et al., 1997). Its expression in the immature CNS has been linked to neuroprogenitor proliferation (Reynolds et al., 1992), astrogliogenesis (Weickert and Blum, 1995; Burrows et al., 1997), and the onset of puberty (Ojeda et al., 1997). In adults, TGF $\alpha$ is expressed by subsets of neurons and astrocytes throughout the CNS (Wilcox and Derynck, 1988; Kudlow et al., 1989; Fallon et al., 1990; Seroogy et al., 1993; Ferrer et al., 1995), but its functions remain elusive.

A potential link between TGF $\alpha$ and astrogliosis has been unraveled by studies of pathological situations. Astrogliosis is

\footnotetext{
Received July 7, 1998; revised Sept. 21, 1998; accepted Sept. 22, 1998.

This research was supported by Institut National de la Santé et de la Recherche Médicale [postdoctoral fellowship (A.G.R.)] and the Association Française Contre les Myopathies (A.F.M.). We are grateful to Dr. Glenn T. Merlino for the generous donation of the transgenic mice used to breed for our experiments, Dr. N. Abrous for help in the design of the BrdU experiments, and Dr. Pierre Drapeau for review of this manuscript. We thank Drs. J. Cadusseau and M. Peschanski for helpful discussions.

Correspondence should be addressed to Marie-Pierre, Junier Institut National de la Santé et de la Recherche Médicale U421, Faculté de Médecine, 8 rue du Général Sarrail, 94010 Créteil cedex, France.

Dr. Rabchevsky's present address: 229 Sanders-Brown Research Center on Aging, University of Kentucky, 311 Sanders-Brown Building, Lexington, KY 40536-0230.

Dr. Weinitz's present address: Erikslustv 36 F, 21773 Malmoe, Sweden.

Dr. Coulpier's present address: Regeneron Pharmaceuticals, 777 Old Saw Mill River Road, Tarrytown, NY 10591-6707.

Copyright (C) 1998 Society for Neuroscience $\quad 0270-6474 / 98 / 1810541-12 \$ 05.00 / 0$
}

characterized by profound changes in astrocytes, which pass from quiescent to activated morphologies and metabolic profiles (Eddleston and Mucke, 1993; Ridet et al., 1997). This process is systematically associated with neurodegenerative diseases and CNS trauma (Norenberg, 1994). Molecular mechanisms that control the initial states of its development in vivo are, nonetheless, poorly understood. Overexpression of TGF $\alpha$ and EGFR occurs in reactive astrocytes after a broad range of insults, which include disruption of the tissue architecture, such as a cellular graft within the striatum (Back et al., 1993), electrolytic lesion of the hypothalamus (Junier et al., 1991, 1993), excitotoxically induced neuronal loss in the thalamus (M. P. Junier and M. Peschanski, unpublished data), and entorhinal ablation (Nieto-Sampedro et al., 1988). Astrogliosis developing at a distance from the injury site, such as after motor nerve crush, is also accompanied by upregulation of both $\mathrm{TGF} \alpha$ and EGFR. In this case, injured neurons are the first to synthesize TGF $\alpha$, followed by reactive astrocytes, which bear both the ligand and its receptor (Lisovoski et al., 1997). A similar situation occurs in the murine mutant wobbler, which exhibits a progressive degeneration of spinal motoneurons (Junier et al., 1994a).

These data, associated with the mitotic, trophic, and differentiative effects of TGF $\alpha$ on cultured astrocytes (Kimura et al., 1990; Han et al., 1992; Ma et al., 1994a, 1997; Miller et al., 1995; Faber-Elman et al., 1996; Mazzoni and Kenigsberg, 1997), favor a role for this factor in the control of astrogliosis. They do not, however, reveal whether TGF $\alpha$ is sufficient by itself to trigger astrogliosis in vivo or, rather, takes part in the response to a different inductive signal. We addressed this question by using transgenic mice that bear the human $\mathrm{TGF} \alpha$ cDNA under the 
Figure 1. Evaluation by ribonuclease protection assay of hTGF $\alpha$ transgene mRNA levels in the cervical spinal cord of transgenic mice fed with either water $(T)$ or zinc-supplemented water $(T+$ Zinc $)$. The hTGF $\alpha$ mRNA is expressed in water-fed transgenic mice. First lane, Undigested hTGF $\alpha$ cRNA probe; second lane, digested hTGF $\alpha$ cRNA probe. Mean $\pm \mathrm{SD} ;{ }^{*} p<0.01 ; n=3$.

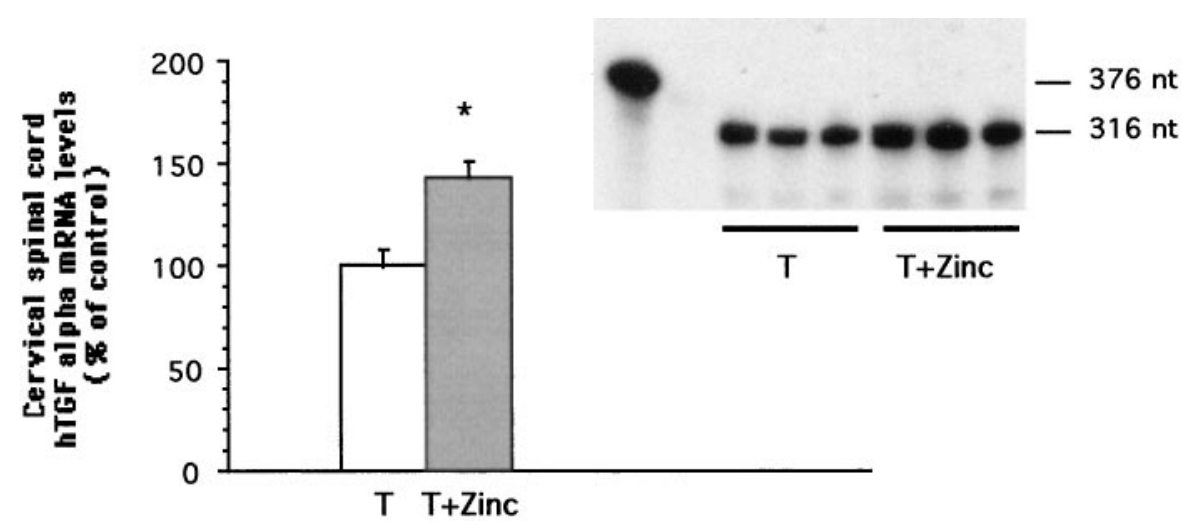

control of a ubiquitous promoter, the zinc-inducible mouse metallothionein 1 promoter (MT1-hTGF $\alpha$ mouse; Jhappan et al., 1990). Because the transgene is expressed within the brain (Jhappan et al., 1990; Ma et al.; 1994b), we were able to explore the possible occurrence of astrogliosis in uninjured adult mammalian nervous tissues exposed to enhanced TGF $\alpha$ expression.

\section{MATERIALS AND METHODS}

Animals. Adult MT1-hTGF $\alpha$ transgenic mice from the MT-42 line were a gift from Dr. G. Merlino (National Cancer Institute, Bethesda, MD). This transgenic line has been described in detail by Jhappan et al. (1990). It carries a 917 bp human TGF $\alpha$ cDNA under the control of the zinc-inducible mouse metallothionein 1 promoter. The mice were bred in an air-conditioned room with free access to water and food, and 3 weeks after birth they were separated and housed by sex. Only homozygous animals were used. At 7 weeks of age, both sexes of MT1-hTGF $\alpha$ transgenic mice and age-matched controls corresponding to the parental CD1 strain (Charles River) were given solutions of $25 \mathrm{~mm}$ zinc chloride in mineral water to drink ad libitum. Daily measurements confirmed they were drinking. The animals were killed after 3 weeks of zinc delivery either for tissue dissection to extract RNA and protein or for perfusion fixation. The CNS areas examined were the hippocampus, the striatum, and the cervical spinal cord. For the determination of cellular proliferation, mice received repeated intraperitoneal injections of 5' -bromo-2'- deoxyuridine (BrdU, $50 \mathrm{mg} / \mathrm{kg}$ body weight; Sigma, St. Louis, MO). The injection regimen was as follows: $9 \mathrm{~d}$ (one injection in the evening), $8 \mathrm{~d}$ (two injections at $6 \mathrm{hr}$ intervals), and one $\mathrm{d}$ (three injections at $5 \mathrm{hr}$ intervals) before killing. This regimen was chosen to ensure an eventual detection of proliferation, migration, and astrocytic differentiation of subependymal cells within the striatum (Craig et al., 1996).

Extraction of RNA and protein. Mice were overdosed with pentobarbital; the CNS was rapidly removed; and the hippocampus, the striatum, and the cervical portion of the spinal cord were dissected at $4^{\circ} \mathrm{C}$ before being stored at $-80^{\circ} \mathrm{C}$ until further use. mRNA and protein were obtained from the same tissue samples using the Trizol reagent and following the manufacturer's protocols (Life Technologies). For the assay of phosphorylated EGFR protein, animals having received zinc in their drinking water for 2 and 3 weeks were used, and the dissected striata were homogeneized at $4^{\circ} \mathrm{C}$ in TG buffer $(62.5 \mathrm{~mm}$ Tris, $\mathrm{pH}$ 6.8, $10 \%$ Triton $\mathrm{X}-100,10 \%$ glycerol, $10 \mu \mathrm{g} / \mathrm{ml}$ aprotinin, $2 \mathrm{~mm}$ PMSF, $2 \mathrm{~mm}$ EDTA, and $1 \mathrm{~mm}$ sodium orthovanadate). The homogenates were centrifuged to remove the cellular debris, and the supernatants were stored at $-80^{\circ} \mathrm{C}$ until further use. The protein contents were determined using the BCA kit (Pierce, Interchim).

Northern blot analysis. Total RNA (10 $\mu \mathrm{g} /$ lane) was size-fractionated in agarose/formaldehyde gels and blotted onto nitrocellulose membranes. The hTGF $\alpha$ transgene, glial fibrillary acidic protein (GFAP), and cyclophilin mRNAs were successively identified by hybridization to the following cDNA probes labeled using the random primer method and
A

Figure 2. GFAP expression in the hippocampus of MT1-hTGF $\alpha$ mice versus controls. A, top panel, Example of Northern blot analysis of GFAP mRNA levels. The expression of human TGF $\alpha$ mRNA was confirmed in the transgenic mice, and cyclophilin mRNA served as an internal standard. Bottom panel, Densitometric analysis of GFAP mRNA signals. Note the prominent increase of GFAP mRNA in transgenic mice versus controls. Mean $\pm \mathrm{SD} ;{ }^{*} p<$ $0.01 ; n=3$. B, top panel, Example of Western blot analysis of GFAP protein levels in the hippocampus. Bottom panel, Densitometric analysis of GFAP protein signals. Mean $\pm \mathrm{SD} ;{ }^{*} p<0.05$; $n=3-4$. C, Control mice; $T$, transgenic mice.
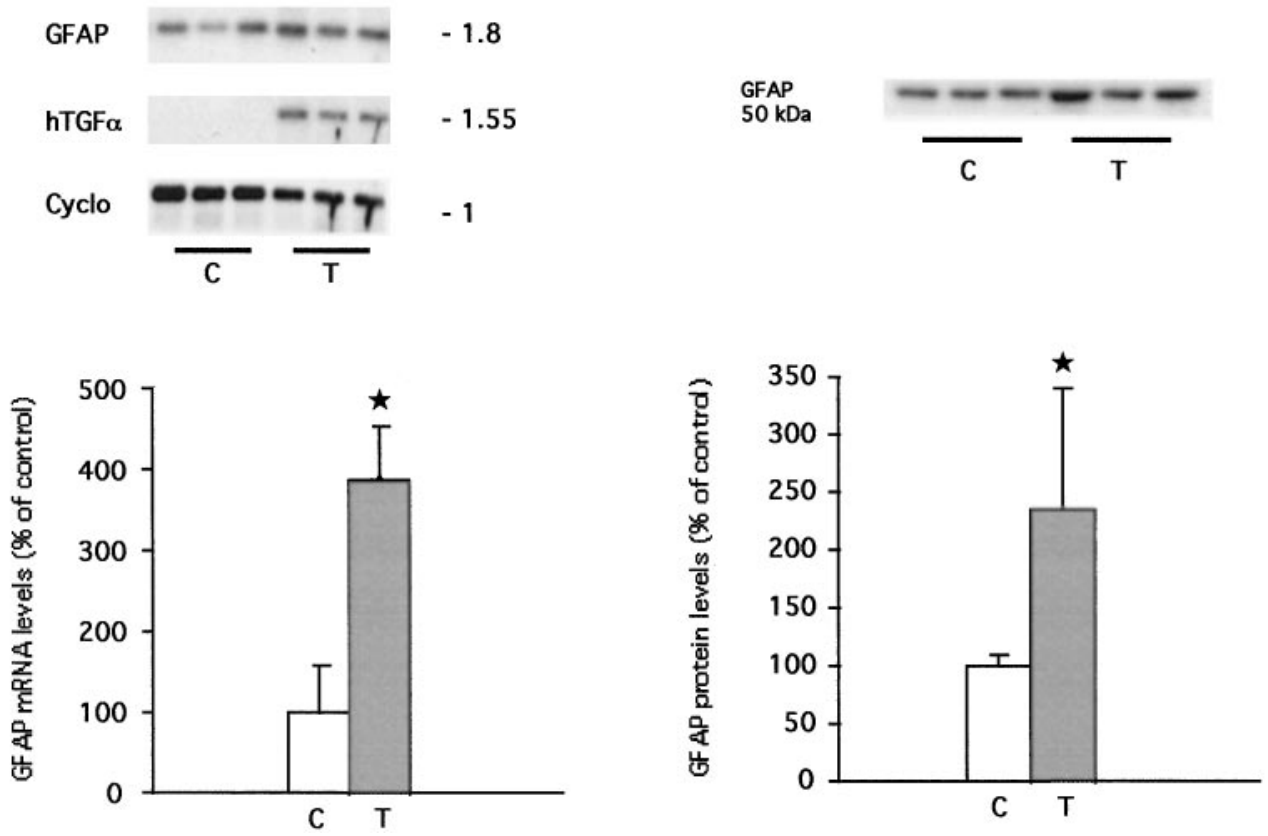
A

STRIATUM
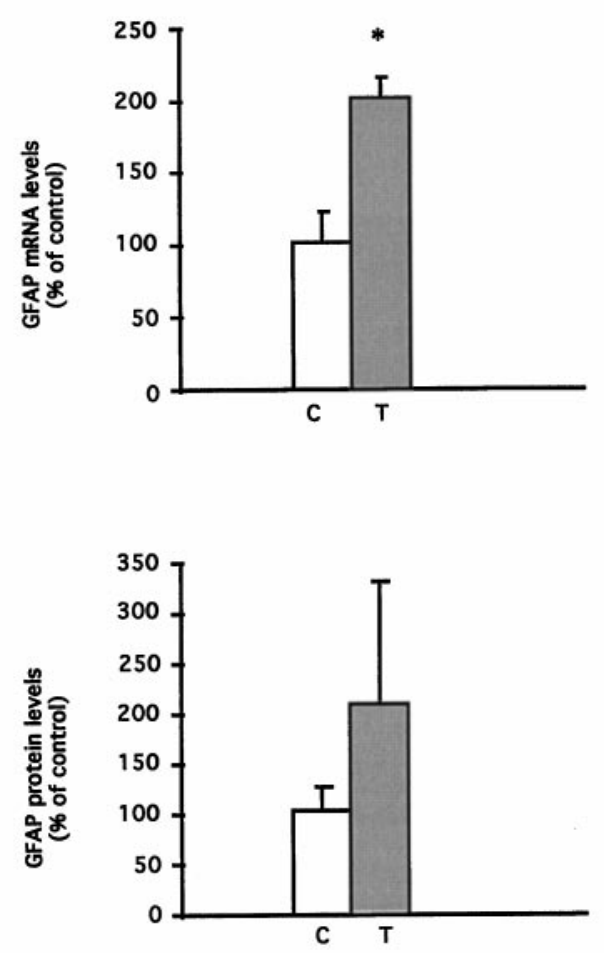

B

CERVICAL SPINAL CORD

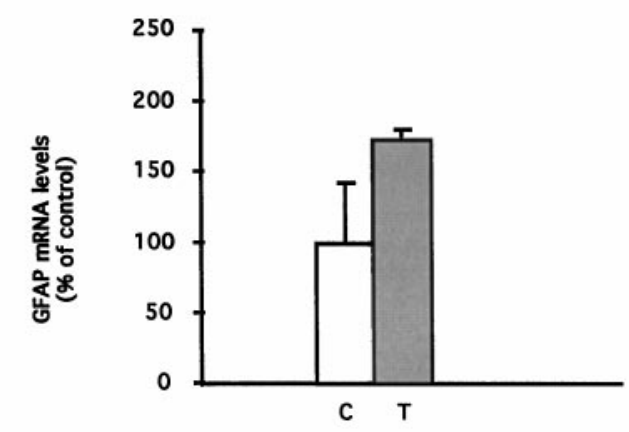

Figure 3. A, GFAP expression in the striatum of MT1-hTGF $\alpha$ mice versus controls. Top panel, mRNA levels analyzed by Northern blot. Mean $\pm \mathrm{SD}$; ${ }^{*} p<0.01 ; n=3$. Bottom panel, protein levels analyzed by Western blot. Mean $\pm \mathrm{SD}$; nonsignificant; $n=3$. $B$, GFAP expression in the cervical spinal cord of MT1-hTGF $\alpha$ mice versus controls. Top panel, Densitometric analysis of GFAP mRNA signals detected by Northern blot. Mean \pm SD; nonsignificant; $n=3$. Bottom panel, Densitometric analysis of GFAP protein signals detected by Western blot. Mean \pm SD; * $p=0.001 ; n=5$. $C$, Control mice; $T$, transgenic mice.
[ ${ }^{32} \mathrm{P}$ ]dCTP: 316 bp hTGF $\alpha$ cDNA fragment (Jhappan et al., 1990), $1.2 \mathrm{~kb}$ cDNA fragment of the mouse GFAP cDNA (Lewis et al., 1984), and $1 \mathrm{~kb}$ rat cyclophilin cDNA (Danielsson et al., 1988). The blots were exposed to Amersham (Arlington Heights, IL) Hyperfilms, and the autoradiograms were analyzed by laser densitometry using the cyclophilin mRNA signal to standardize GFAP mRNA values (Junier et al., 1994b).

Ribonuclease protection assay. The hTGF $\alpha$ antisense RNA probe was obtained by in vitro transcription of a $316 \mathrm{bp}$ hTGF $\alpha$ cDNA fragment (Jhappan et al., 1990) cloned into the pGEM3Z vector, linearized with EcoRI, and transcribed with SP6 RNA polymerase in presence of $\left[{ }^{32} \mathrm{P}\right] \mathrm{CTP}$. The ribonuclease protection assay was performed as previously described in detail (Junier et al., 1991) using $10 \mu \mathrm{g}$ of cervical spinal cord total RNA per tube.

Western blot analysis of GFAP and vimentin. Western blot analysis was performed as previously described (Andres-Barquin et al., 1994) using 2 $\mu \mathrm{g}$ of protein per lane. Polyclonal anti-GFAP antibody (1:100; Dakopatts, Dako, Glostrop, Denmark) or monoclonal anti-vimentin antibody (V9; Boehringer, Bagnolet, France) were used to probe the nitrocellulose membranes. After incubation with the appropriate secondary antibody, either coupled to ${ }^{125} \mathrm{I}$ (anti-rabbit 1:160, Amersham) or to horseradish peroxidase (HRP) (anti-mouse 1:2500, Amersham), the membranes were either directly exposed to Amersham Hyperfilms or after revelation of the HRP activity with the enhanced chemiluminescent (ECL) procedure (Amersham). The autoradiograms were analyzed by laser densitometry.

Phosphorylated EGFR assay. The EGFR was immunoprecipitated using a rabbit polyclonal antibody directed against the receptor (Santa Cruz Biotechnology, Santa Cruz, CA) and protein A-Sepharose beads as previously described using $300 \mu \mathrm{g}$ of proteins and $3 \mu \mathrm{l}$ of antibody (Ma et al., 1994c). The immunoprecipitates were then loaded on $7 \%$ SDSPAGE and transferred to a nitrocellulose membrane. Cell lysates from the A-431 epithelial cell line were used as positive controls. The membranes were incubated with a monoclonal anti-phosphotyrosine antibody (1:3000 dilution, Sigma), followed by an anti-mouse antibody coupled to HRP (1:10,000; Amersham, Les Ulis, France). Revelation of the HRP activity using the ECL procedure (Amersham) was followed by exposure of the membranes to Hyperfilms. To evaluate the amount of EGFR regardless of its phosphorylation, the membranes were stripped and incubated with the polyclonal anti-EGFR antibody (1:1000, Santa Cruz). The following steps were identical, except that the secondary antibody was an anti-rabbit coupled to HRP (Amersham). The autoradiograms were analyzed by laser densitometry.
Immunohistochemistry. Mice were overdosed with $4 \%$ chloral hydrate and perfused with $0.1 \mathrm{M}$ PBS (pH 7.4), followed by $4 \%$ paraformaldehyde in PBS. Preliminary immunohistochemical observations revealed no overt differences between the GFAP immunoreactivity in MT1-hTGF $\alpha$ transgenic males and females. Three transgenic and three control mice of both sexes were used for immunohistochemistry. For Mac-1 (rat antiCD11b receptor) immunohistochemistry, some mice were perfused with periodate-lysine-paraformaldehyde fixative (McLean and Nakane, 1974). The dissected CNS tissues were post-fixed in their respective fixatives for $4 \mathrm{hr}$ at $4^{\circ} \mathrm{C}$, cryoprotected in $30 \%$ sucrose in PBS at $4^{\circ} \mathrm{C}$ until the tissue sank, frozen in $-40^{\circ} \mathrm{C}$ isopentane, and stored at $-80^{\circ} \mathrm{C}$ until cryosectioning. Free-floating coronal sections $(30 \mu \mathrm{m})$ taken through the cervical spinal cord, the striatum, and the hippocampus were immunostained for either astrocytes or microglial cells using rabbit anti-GFAP (1:2000, Dakopatts) or Mac-1 (1:100, Serotec, Oxford, UK), respectively. Biotinylated secondary antibodies were from Vector Laboratories (1:300), and the ABC method was used with VIP as the chromogen (Vector). Before staining, sections were incubated in $0.2 \% \mathrm{H}_{2} \mathrm{O}_{2}$ in PBS for $20 \mathrm{~min}$ to quench endogenous peroxidase activity. The immunohistochemical detection of EGFR and its co-localization with GFAP was achieved following the same procedure with the following modifications: tissue slices obtained from fresh snap-frozen tissues were fixed in methanol for 10 min at $-20^{\circ} \mathrm{C}$ as previously described (Weickert and Blum, 1995); the anti-EGFR polyclonal antibody was used at a 1:50 dilution (Upstate Biotechnology, Lake Placid, NY), and the chromogens corresponded to DAB and DAB-nickel (Vector). The immunohistological detection of BrdU was performed according to previously described procedures (Nowakowski et al., 1989) using the monoclonal anti-BrdU at a 1:400 dilution (Accu-Specs).

Quantification of GFAP-immunoreactive astrocytes and of BrdUimmunoreactive cells. For each of the three regions examined, three sections separated by $\sim 100 \mu \mathrm{m}$ were analyzed from three control and three transgenic mice, and both the right and left sides of the corresponding regions were quantified. The method for counting the number of GFAP-immunoreactive astrocytes used the Bioquant image analysis program (Raul Biometrics, Inc., Memphis, TN) with software connected to a stage encoder (Boeckler Instruments, Tucson, AZ), which allows the computer to interpret any $x$-, $y$-, and $z$-axis movement of the microscope stage. At low power the regions of interest were marked, the magnification was increased to $160 \times$, and the number of GFAP-immunoreactive cells within a $40,000 \mu \mathrm{m}^{2}$ window was counted. For the cervical spinal 
A

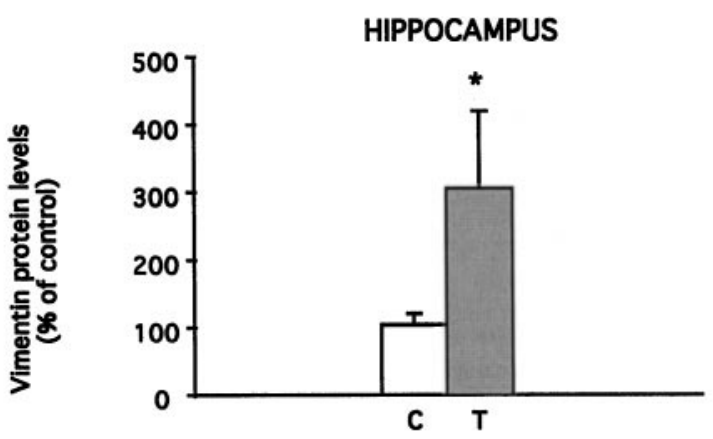

B

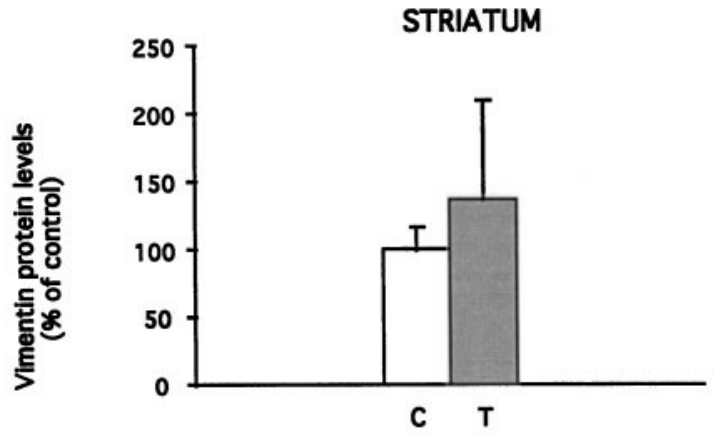

C

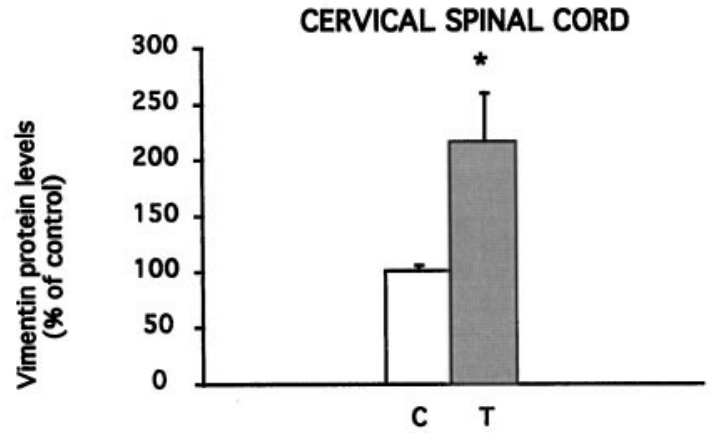

Figure 4. Densitometric analysis of vimentin protein levels of transgenic and control mice detected by Western blot in the hippocampus $(A)$ (mean $\left.\pm \mathrm{SD} ;{ }^{*} p=0.01 ; n=3-4\right)$, the striatum $(B)$ (mean $\pm \mathrm{SD}$; nonsignificant; $n=6$ ), and the cervical spinal cord (C) (mean $\pm \mathrm{SD} ;{ }^{*} p<$ $0.01 ; n=3$ ). $C$, Control mice; $T$, transgenic mice.

cord the counting window was centered in the ventral horns; for the hippocampus it was placed in the molecular layer of the dentate gyrus; and in the striatum two separate windows distanced by $200 \mu \mathrm{m}$ both in the $x$ and $y$ planes were placed in the dorsomedial striatum, bilaterally. The number of cells counted in each section on both the right and left sides for each region was averaged. Quantification of BrdUimmunoreactive cells was done in a similar manner but with counting windows increased to $60,000 \mu \mathrm{m}^{2}$ in the ventral horn of the cervical spinal cord and $0.84 \mathrm{~mm}^{2}$ in the striatum.

Statistical analysis. Differences between groups were evaluated by an unpaired Student's $t$ test. A level of significance of $p<0.05$ was considered statistically significant.

\section{RESULTS}

The most widespread and characteristic hallmark of reactive astrocytes is an increased expression of GFAP, coupled with a hypertrophied morphology, including enlarged somata and thickened processes (Dahl and Bignami, 1974; Bignami and Dahl, 1976; Eng, 1988). Both parameters were used as indices of astrogliosis in each CNS region examined: the hippocampus, the striatum, and the cervical spinal cord. In addition, we evaluated the protein levels of another intermediate gliofilament, vimentin, known to be upregulated with GFAP in reactive astrocytes (for review, see Eddleston and Mücke, 1993; Norenberg, 1994). Zinc stimulates the mouse metallothionein promoter, which controls transcription of the hTGF $\alpha$ transgene (Jhappan et al., 1990; Hidalgo et al., 1994; Ma et al., 1994b). Although the nervous tissues contain relatively high levels of zinc under normal conditions (Smart et al., 1994), we chose to ensure a maximal expression of the transgene by supplementing the drinking water of the adult experimental animals with $25 \mathrm{~mm} \mathrm{ZnCl}_{2}$ for 3 weeks before killing. This period was chosen with regard to the $2-3$ week delay we observed between infliction of various types of CNS injuries and the full development of astrogliosis (Junier et al., 1994a,b; Lisovoski et al., 1997). Levels of hTGF $\alpha$ transgene mRNA with and without zinc supplementation were evaluated in the cervical spinal cord of adult transgenic mice using ribonuclease protection assay (Fig. 1). A $45 \%$ increase of the transgene mRNA levels was noted in the cervical spinal cord of transgenic mice fed with zinc-supplemented water compared with transgenic mice fed with water (Fig. 1).

Changes in GFAP expression in the hippocampus, striatum, and cervical spinal cord of MT1-hTGF $\alpha$ mice

The consequences of TGF $\alpha$ overproduction on the metabolism of astrocytes was first explored through assessment of GFAP expression at the mRNA and protein levels.

Figure $2 A$ depicts an example of Northern blot analysis of GFAP and human TGF $\alpha$ mRNA, whereas Figure $2 B$ represents the corresponding Western blot analysis of GFAP protein. As expected, hTGF $\alpha$ mRNA was present only in the transgenic tissues (Fig. 2A). Densitometric analysis of the signals obtained by Northern blot hybridization revealed a sharp increase in GFAP mRNA levels in the hippocampus of transgenic mice compared with controls (Fig. $2 A$ ), and GFAP protein levels doubled in the transgenic mice (Fig. $2 B$ ). In the striatum, GFAP mRNA levels were also increased in the transgenic mice compared with controls (Fig. 3A, top panel), whereas protein levels tended to increase without reaching statistical significance (Fig. $3 A$, bottom panel). In the cervical spinal cord of the transgenic mice, GFAP mRNA levels exhibited a modest increase not statistically significant (Fig. 3B, top panel), whereas the protein levels showed a threefold increase (Fig. 3B, bottom panel).

\section{Changes in vimentin expression in the hippocampus,} striatum, and cervical spinal cord of MT1-hTGF $\alpha$ mice

To determine whether GFAP levels were affected in an exclusive manner or whether expression of other intermediate gliofilaments was also stimulated, as often observed in astrogliosis (Norenberg, 1994), the protein levels of vimentin were assayed through Western blot analysis.

Elevated levels of vimentin were detected in the transgenic mice, compared with controls, in the hippocampus (Fig. 4A) and in the cervical spinal cord (Fig. $4 C$ ), whereas in the striatum the measures were heterogeneous among the individual mice examined, ranging from 86 to $258 \%$ of the mean control value (Fig. 4B).

Thus, TGF $\alpha$ overexpression is accompanied with enhanced levels of at least two structural proteins specific to astrocytes, GFAP and vimentin.

\section{Morphological alterations of the astrocytes in the MT1-hTGF $\alpha$ mice}

Modifications in the morphology of astrocytes were evaluated using GFAP immunohistochemistry, and the average number of 

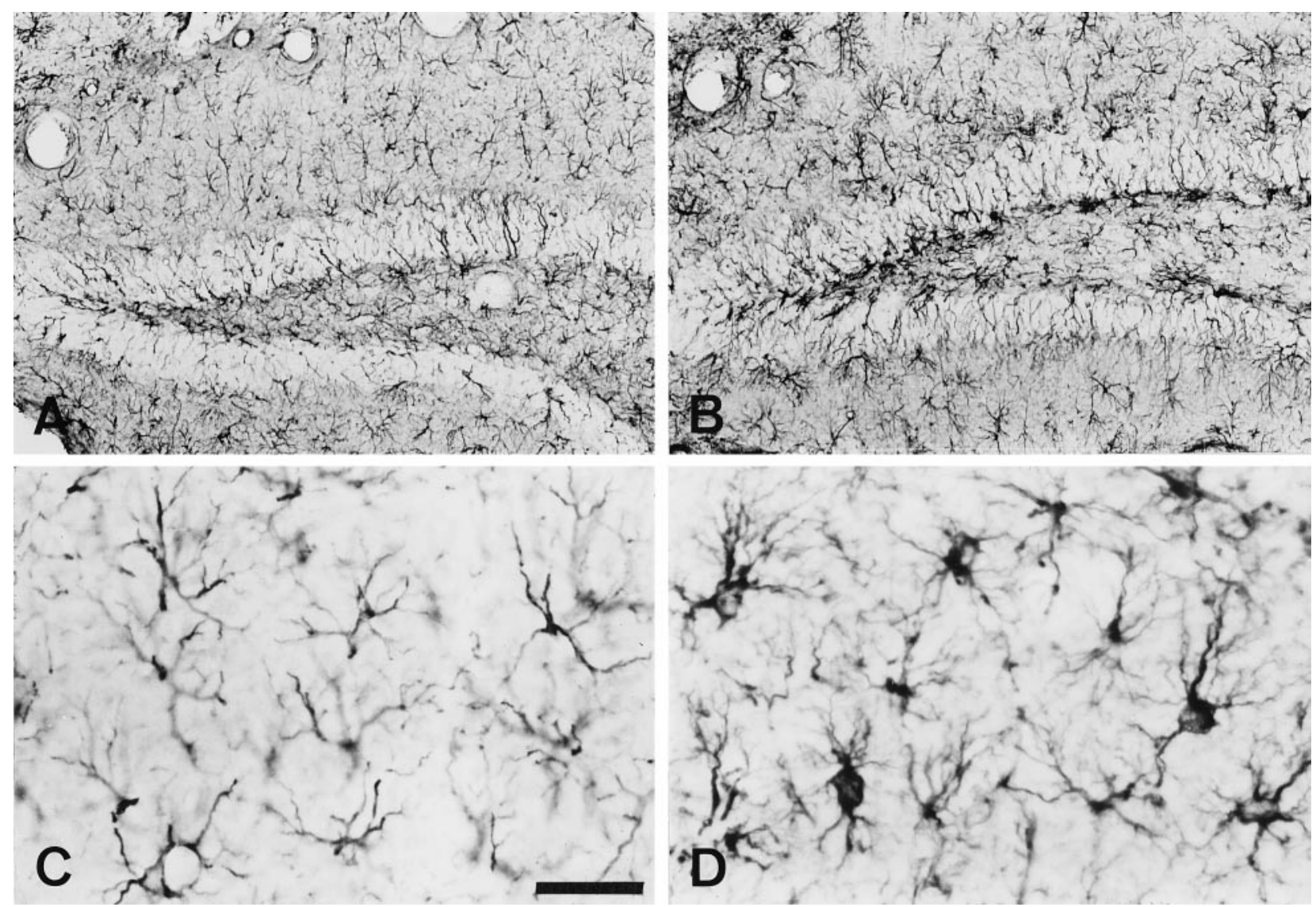

Figure 5. Immunohistochemical staining for GFAP in the hippocampus of controls $(A, C)$ versus transgenic mice $(B, D)$. Although the number of GFAP-immunoreactive astrocytes in the transgenic mice was similar to controls $(A$ vs $B)$, the astrocytes in the transgenic hippocampus exhibited larger cell bodies and thicker processes ( $C$ vs $D)$. Scale bar: $A, B, 100 \mu \mathrm{m} ; C, D, 20 \mu \mathrm{m}$.

GFAP-immunoreactive astrocytes was determined in each region over a 40,000 $\mu \mathrm{m}^{2}$ area (see Materials and Methods).

In the hippocampus of transgenic mice, the increase in GFAP protein levels was manifested by an increase in the overall GFAP immunolabeling of astroglial cells (Fig. 5A,B). The GFAPimmunoreactive astrocytes in the transgenic mice exhibited larger cell bodies and thicker processes than in controls (Fig. 5C,D), but the number of labeled cells was unchanged in the transgenic hippocampus $(24.8 \pm 1.8$ in controls vs $27.0 \pm 4.0$ in transgenes, mean $\pm \mathrm{SD} ; n=6$; nonsignificant).

In the striatum, immunohistochemical staining revealed a threefold increase in the number of GFAP-immunoreactive astrocytes in the transgenic mice (Fig. $6 A, B, 4.8 \pm 1.7$ in controls vs $14.1 \pm 2.2$ in transgenes, mean $\pm \mathrm{SD} ; n=6 ; p<0.001)$. The immunolabeled astrocytes in controls were widely dispersed and characterized by delicate arborizations of thin, highly branched processes extending from inconspicuous somata (Fig. 6C). In sharp contrast, transgenic mice demonstrated complex networks of thick astrocytic processes interspersed with strongly GFAPimmunoreactive cell bodies (Fig. 6D). These astrocytic networks were seen throughout the striatum and were similar whether the transgenic mice had or not received zinc in their drinking water (data not shown).

An increase in the number of GFAP-immunoreactive astrocytes was also observed in the spinal cord gray matter of transgenic mice (Fig. $7 C, D ; 8.0 \pm 0.9$ in controls vs $14.1 \pm 2.4$ in transgenic mice, mean $\pm \mathrm{SD} ; n=6 ; p<0.001)$. Compared with controls, in which immunolabeled astrocytes displayed quiescent morphologies (Fig. 7C, inset), the parenchymal astrocytes of transgenic mice demonstrated pronounced immunolabeling associated with a profusion of thick processes and evidence of cytoplasmic hypertrophy (Fig. 7D, inset). We also observed an augmentation in the density and thickness of immunostained astrocytic processes coursing in the white matter of transgenic mice compared with controls (Fig. $7 A, B$ ). The pattern of GFAP immunolabeling was similar in the cervical spinal cord of transgenic mice fed either with water or with zinc-supplemented water (data not shown).

Incorporation of BrdU in the DNA of dividing cells was used to determine whether the enhanced numbers of astrocytes observed in the striatum and the cervical spinal cord resulted from astrocytic proliferation. As expected, numerous BrdU-immunoreactive nuclei were observed at the dorsal tip of the lateral ventricle (Fig. 8B), where subependymal progenitor cells are located (Tropepe et al., 1997), ensuring the efficacy of the technical procedure. In contrast, only rare BrdU-immunoreactive nuclei were observed in the striatum (Fig. $8 C$ ) of both transgenic and control mice as well as in the ventral horn of the cervical spinal cord. The number of BrdUimmunoreactive nuclei in either structure was similar in control and transgenic mice (Fig. $8 A$ ).

These immunohistological experiments demonstrated that the enhanced expression of GFAP and vimentin was accompanied by the appearance of astrocytes with reactive morphologies in the 

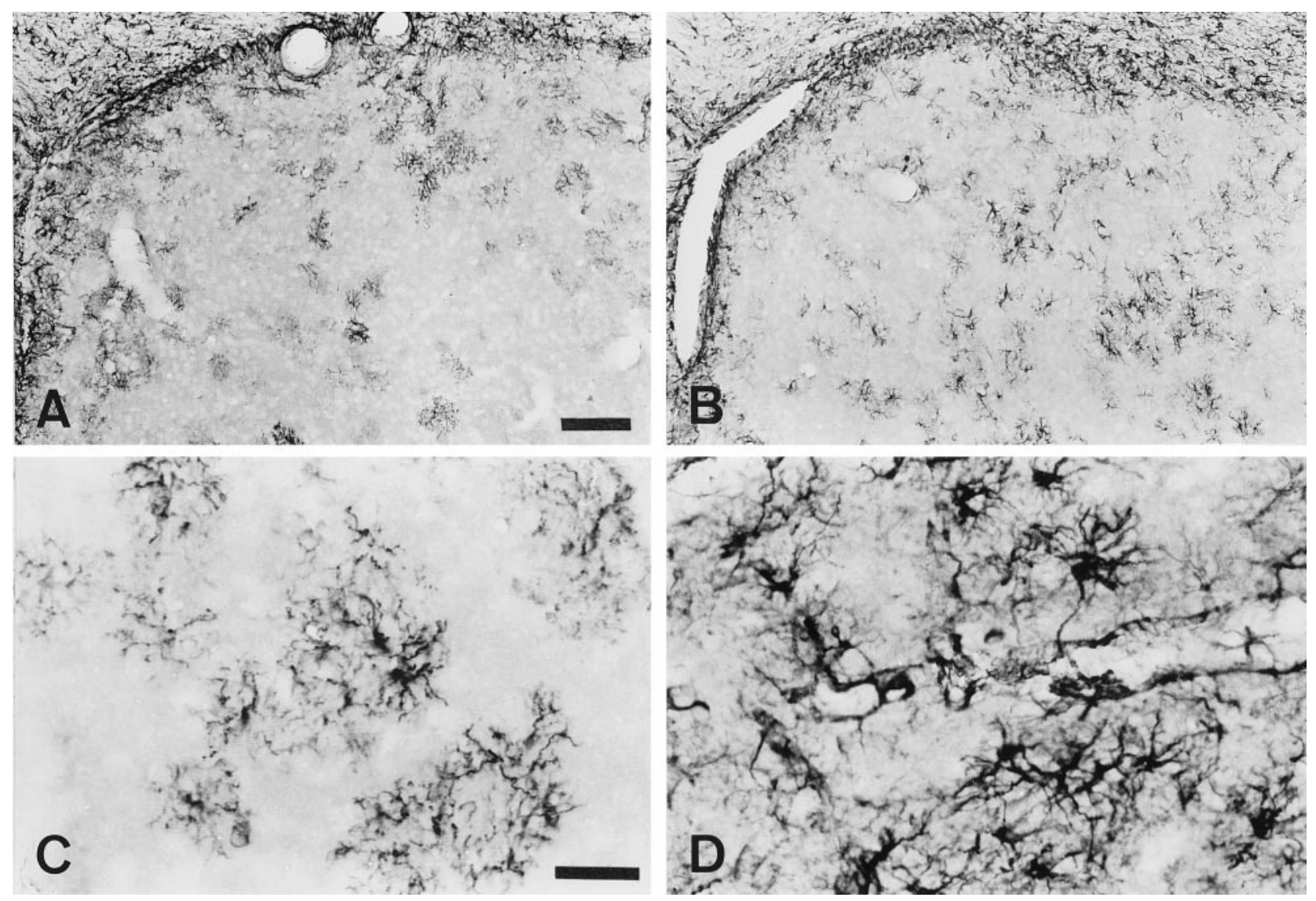

Figure 6. Immunohistochemical staining for GFAP in the striatum of controls $(A, C)$ versus transgenic mice $(B, D)$. $A, B$, At low magnification, the number of GFAP-immunoreactive astrocytes in the striatum of transgenic mice $(B)$ was higher than in controls $(A)$. $C, D$, At higher magnification, the astrocytes in controls exhibited a quiescent morphology, with thin, highly branched processes $(C)$, whereas in transgenic mice $(D)$ astrocytes demonstrated reactive phenotypes characterized by increased numbers of labeled processes, many of which appearing retracted, as well as hypertrophied somata. Scale bars: $A, B, 100 \mu \mathrm{m} ; C, D, 30 \mu \mathrm{m}$.

three structures studied and an increase in the number of GFAPimmunoreactive astrocytes in the striatum and the cervical spinal cord, whereas the number of proliferating cells remained unchanged.

\section{Activation of EGFR in the striatum of MT1-hTGF $\alpha$ mice}

Ligand-dependent activation of the EGFR intrinsic tyrosine kinase is an essential step in the signal transduction mechanism that mediates biological actions of TGF $\alpha$ (Carpenter and Cohen, 1990). To determine whether TGF $\alpha$ stimulatory effects in the transgenic mice were accompanied by the activation of its receptor, we evaluated the levels of phosphorylated EGFR in the striatum, the structure exhibiting the most striking alterations of its astrocyte population. A 2- to 2.5-fold increase in the levels of phosphorylated EGFR was observed in the striatum of transgenic mice compared with controls (Fig. 9A). Cellular localization of the EGFR protein in the striatum was achieved using double immunohistochemistry with antibodies to the receptor and to GFAP. The results showed that EGFR was expressed by astrocytes throughout the striatal parenchyma, the immunohistochemical deposit being preferentially concentrated over the cell body (Fig. 9B).

\section{Immunohistochemical detection of microglia in the MT1-hTGF $\alpha$ mice}

To determine whether microglial cells were affected by TGF $\alpha$ overproduction, we examined their morphology by immunohisto- chemical detection of the complement type 3 receptor (CR3) using the Mac- 1 antibody, its expression being a very sensitive and specific indicator of microglial activation in the rodent CNS (Graeber et al., 1988).

In contrast to the prominent increases in the number of GFAPimmunoreactive cell bodies and processes in transgenic mice, CR3 immunostaining with Mac-1 antibody revealed that the distribution and morphology of labeled microglia in transgenic mice were not conspicuously modified compared with controls in all regions examined (Fig. $10 A-F$ ). The lack of alteration in microglial morphology was noted regardless of the type of fixative used (see Materials and Methods).

\section{DISCUSSION}

By using transgenic mice that overexpress TGF $\alpha$, we showed that synthesis of this growth factor was sufficient to induce astrogliosis. The salient features of astrogliosis, enhanced GFAP expression and hypertrophic morphology of the astrocytes, were present in each CNS region examined.

\section{Astrocytic reactivity in the MT1-hTGF $\alpha$ CNS}

Our findings of enhanced vimentin levels and of astrocytes with hypertrophic morphologies indicate that the TGF $\alpha$ stimulatory effect is not restricted to GFAP synthesis but affects at least two other aspects of the astrocytic phenotype. Both of them are similarly altered during astrogliosis triggered by pathological in- 

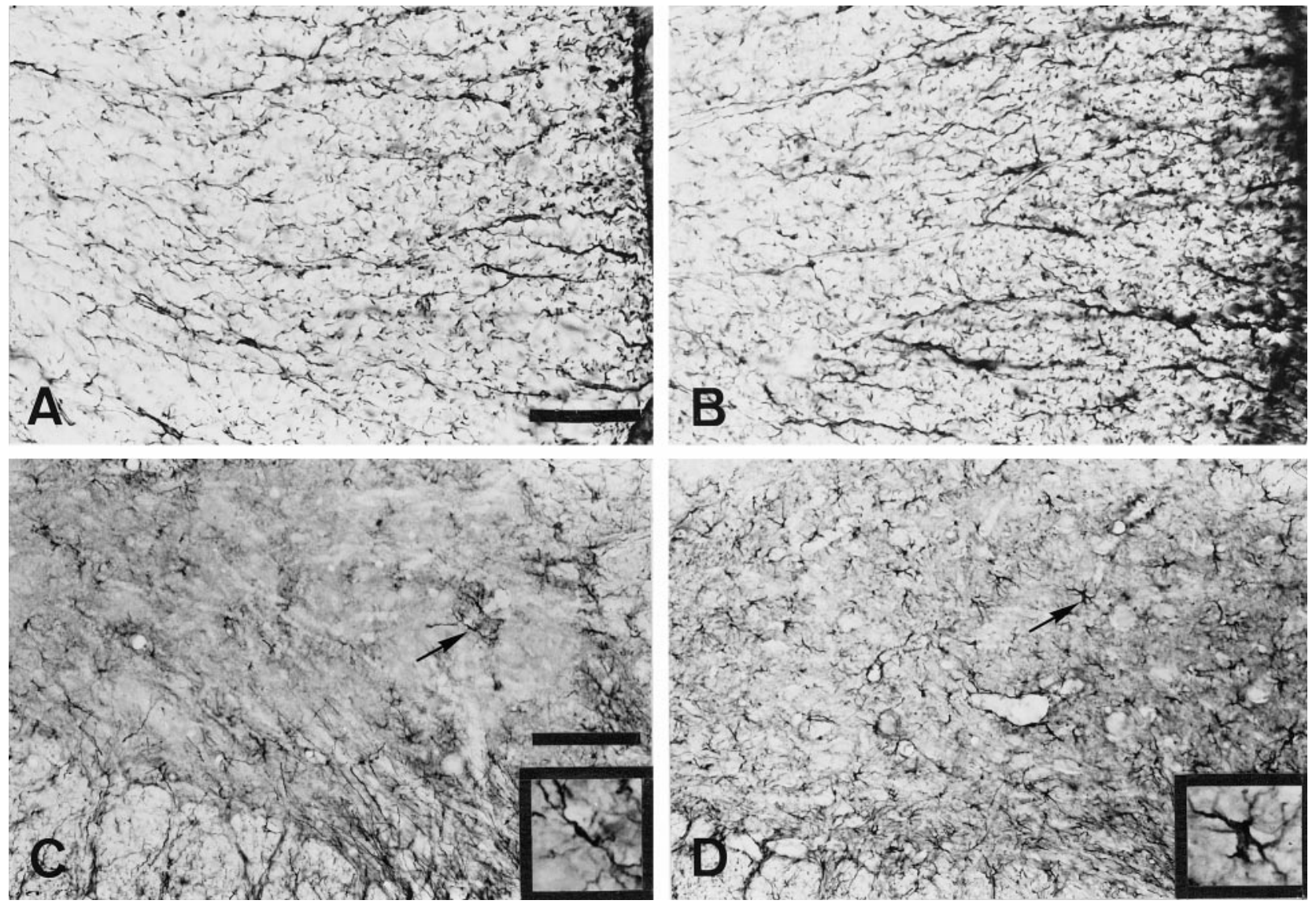

Figure 7. Immunohistochemical staining for GFAP in the cervical spinal cord of controls $(A, C)$ versus transgenic mice $(B, D)$. $A, B$, Views of the ventrolateral region of the spinal cord white matter. Compared with controls $(A)$, there appeared to be an increase in the number and thickness of immunostained astrocytic processes in the white matter of transgenic mice $(B)$. $C, D$, In the gray matter of controls $(C)$, immunolabeled astrocytes were sparsely scattered and had inconspicuous somata with thin processes (inset). In transgenic mice $(D)$, the number of GFAP-immunoreactive astrocytes was increased in the gray matter, and the astrocytes demonstrated a profusion of thick processes and cytoplasmic hypertrophy (inset). The arrows in $C$ and $D$ point to magnified cells in insets. Scale bars: $A, B, 50 \mu \mathrm{m} ; C, D, 100 \mu \mathrm{m}$; insets, $30 \mu \mathrm{m}$.

sults to the CNS. The glial intermediate filament vimentin, normally synthesized in the adult by specialized astrocytes bordering the ventricles and the dura, has been reported in reactive astrocytes (Eddleston and Mücke; 1993; Norenberg, 1994), and the presence of astrocytes displaying hypertrophied morphologies throughout the nervous parenchyma is a characteristic unique to astrogliosis (Reier, 1986; Landis, 1994). The lack of increased numbers of BrdU-labeled nucleus indicates that the enhanced numbers of GFAP-immunoreactive cells detected in the striatum and the spinal cord do not result from mitosis of mature astrocytes or proliferation of adult progenitors (Craig et al., 1996). These observations are in accordance with previous reports showing that although increased numbers of GFAP-immunoreactive cells are often associated with astrogliosis after injuries, most of the increase is attributable to GFAP upregulation in astrocytes already present within the parenchyma, mitotic events contributing only to a small fraction of this augmentation (Amaducci et al., 1981; Smith and Eng, 1988; Norton et al., 1992).

Whether an altered gliogenesis participates in the enhanced astrocyte numbers in the MT1-hTGF $\alpha$ transgenic mice remains to be determined. The suspected participation of TGF $\alpha$ to this developmental process (Weickert and Blum, 1995; Burrows et al., 1997) makes it possible that the increased number of astrocytes in the striatum and cervical spinal cord of the MT1-hTGF $\alpha$ transgenic mice stems, at least in part, from a stimulatory effect of TGF $\alpha$ on the glial precursors. The lack of increased numbers of GFAP-immunoreactive cells in the hippocampus of MT1-hTGF $\alpha$ mice does not, however, support the participation of an enhanced gliogenesis. In this region, the high GFAP levels expressed by the astrocytes in wild-type animals are likely to account for the unaltered numbers of astrocytes. Altogether, these observations suggest rather that the enhanced numbers of astrocytes result from a lowering of the immunohistological detection threshold attributable to GFAP upregulation.

\section{Astrogliosis without microgliosis}

As in the MT1-hTGF $\alpha$ transgenic mice, astrogliosis has been noted in all the explored CNS regions of transgenic mice overexpressing the interleukin-6 (IL-6) or ciliary neurotrophic factor (CNTF) cytokines (Chiang et al., 1994; Fattori et al., 1995; Winter et al., 1995; Heyser et al., 1997). The most striking difference resides in the fact that their overexpression leads not only to astrocytic reactivity but also to the activation of resident microglial cells. Microglial activation is defined by increased cell numbers and/or by morphological alterations (Marty et al., 1991). In MT1-hTGF $\alpha$ transgenic mice, both parameters appeared unchanged. Although lack of alteration in microglial cell morphology and number does not exclude the possibility that subtle metabolic changes may have occurred, our observations suggest 


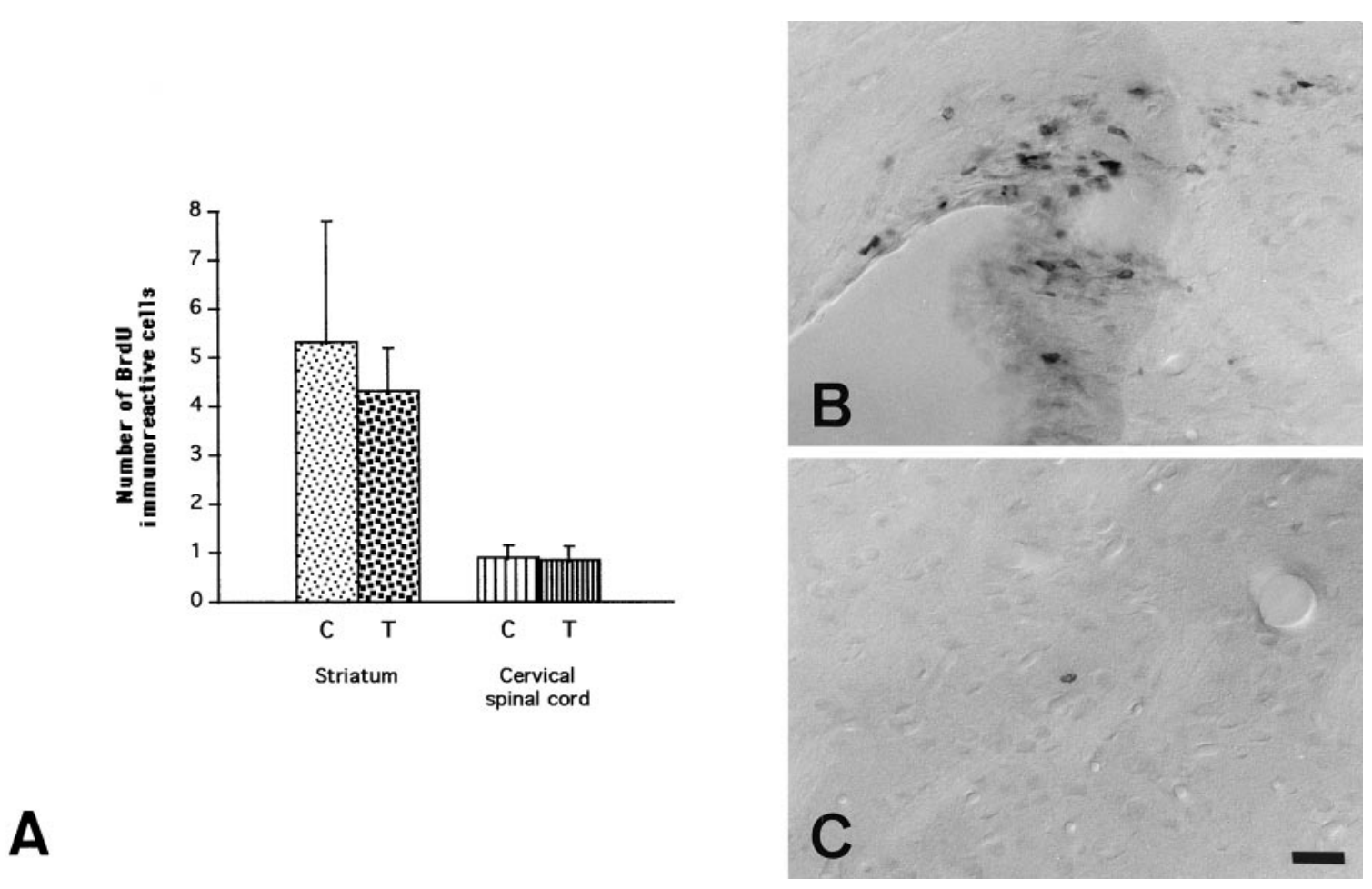

Figure 8. Detection and quantification of proliferating cells by immunohistochemical staining for BrdU. $A$, Numbers of BrdU-immunoreactive nuclei in the striatum and the ventral horn of the cervical spinal cord of control $(C)$ and transgenic mice $(T)$. Mean $\pm \mathrm{SD} ; n=6$. B, Example, in a control mouse, of BrdU-immunoreactive nuclei at the dorsal tip of the lateral ventricle where subependymal progenitor cells are located. $C$, Example of a BrdU-immunoreactive nucleus located in the middle of the striatum of a control mice. Scale bar, $20 \mu \mathrm{m}$.

A

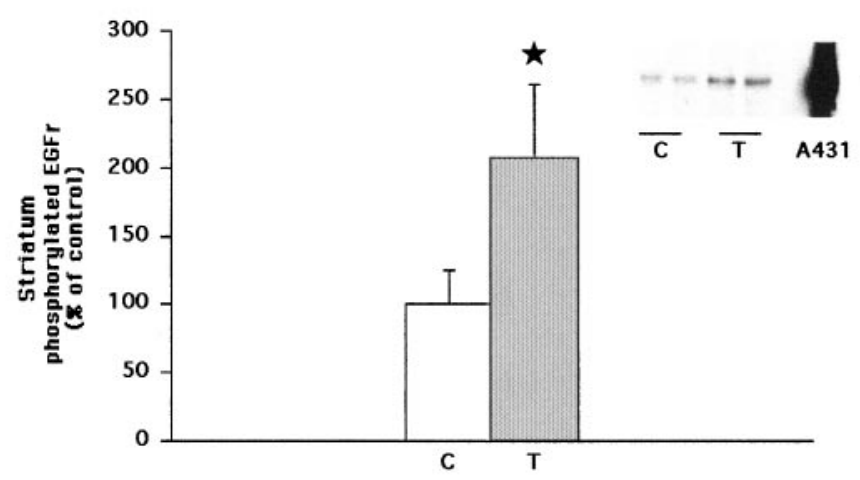

$-180 \mathrm{kD}$

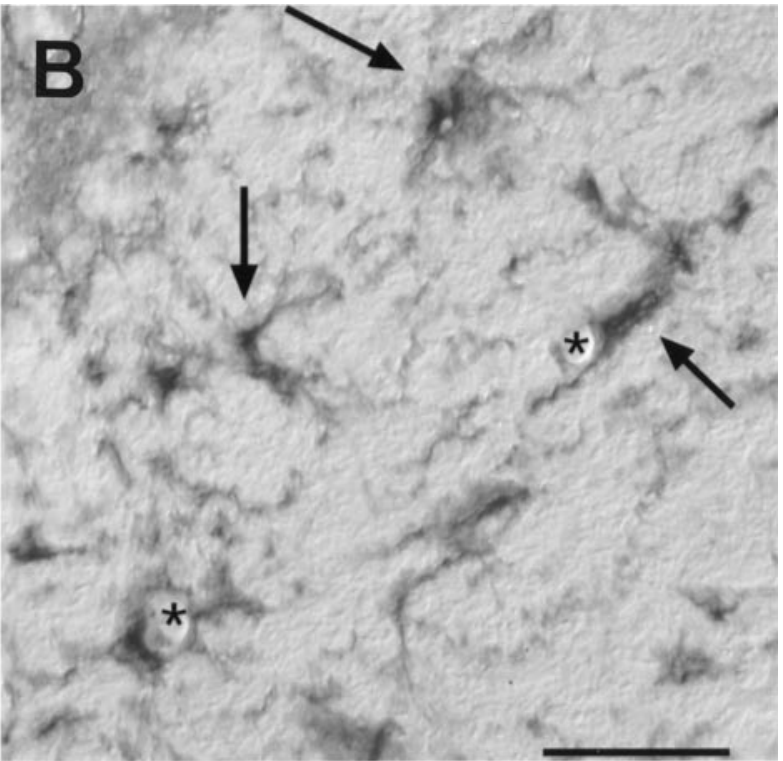

Figure 9. The EGFR in the striatum of MT1-hTGF $\alpha$ mice. $A$, Example of Western blot analysis of phosphorylated EGFR in the striatum of transgenic mice $(T)$ versus controls $(C)$ and densitometric analysis showing a twofold increase in the level of phosphorylated EGFR expression in transgenic mice over controls. Mean \pm SD; ${ }^{*} p=0.001 ; n=4-5$. B. Co-localization of EGFR (black) and GFAP (brown-gold) in the striatum of a transgenic mouse as seen with Nomarski optics. Note that the EGFR immunostaining is essentially localized to the cell body, whereas the GFAP immunostaining extends throughout the cell processes. Asterisks mark blood vessels; arrows point to some of the double-labeled astrocytes. Scale bar, $40 \mu \mathrm{m}$.

that astroglial and microglial reactivity can be dissociated, with distinct signals controlling each event. A dissociation between microglial and astroglial reactivity has also been reported in IL-6 knock-out mice in which the increase in GFAP induced by nerve axotomy is impaired in the facial motor nucleus, whereas micro- glial activation is only reduced (Klein et al., 1997). The cellular localization of the IL-6 and CNTF receptors, astrocytic and neuronal for the first, neuronal and possibly astrocytic for the second (Rudge et al., 1994; Clatterbuck et al., 1996; Klein et al., 1997), precludes the conclusion of whether astrocytes are the 

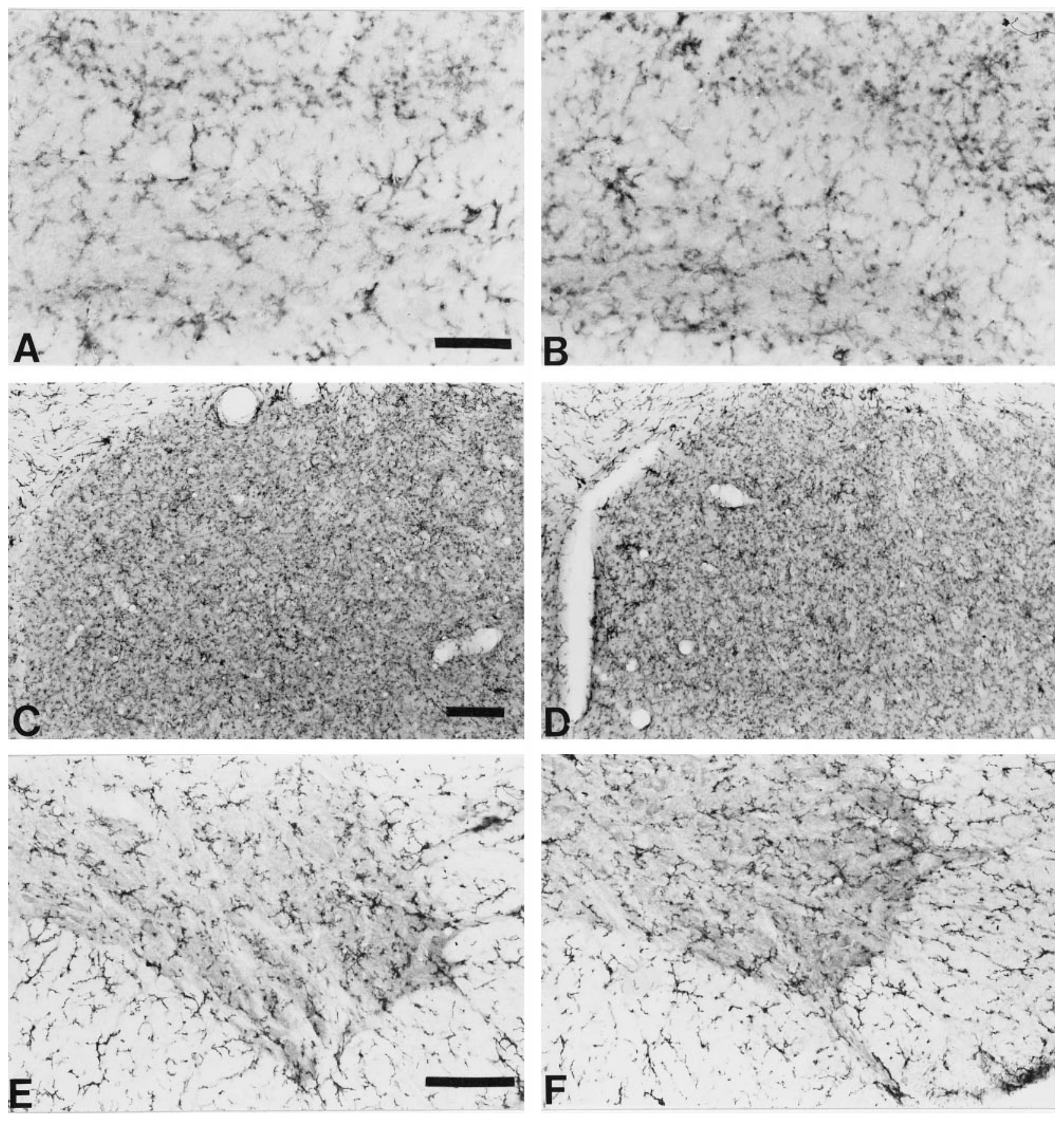

Figure 10. Immunohistochemical detection of microglia in the CNS of MT1-hTGF $\alpha$ mice. Mac-1-immunoreactive cells in controls $(A, C, E)$ versus transgenic mice $(B, D, F)$. The number and morphology of labeled microglial cells were similar in control and transgenic hippocampus $(A, B)$, striatum $(C, D)$, and cervical spinal cord $(E, F)$. Scale bars: $A-D, 20 \mu \mathrm{m} ; E, F, 100 \mu \mathrm{m}$.

primary targets of these cytokines and the subsequent providers of stimulatory signals to the microglial population. But the possibility remains that although astrogliosis may be induced by factors of very different families, the synthetic capabilities acquired by the reactive astrocytes with regard to the production of microglial activators depend on the identity of the inducing molecule. This hypothesis is supported by the lack of microglial activation in face of an intact astrogliosis in the injured facial nucleus of osteopetrosis mice, which are deficient in the macrophage colony-stimulating factor mainly produced by astrocytes (Raivich et al., 1994). Finally, it is interesting to note that the lack of conspicuous microglial reactivity in the MT1-hTGF $\alpha$ mice indicates that TGF $\alpha$ overexpression is unlikely to be accompanied by a significant upregulation of factors such as the CNTF and IL-6 cytokines, which affect both the astroglial and the microglial cell populations.

\section{A direct action of TGF $\alpha$ on the astrocytes}

The lack of marked microglial alteration in the MT1-hTGF $\alpha$ transgenic mice, the detection of enhanced levels of phosphorylated EGFR, and their astrocytic localization argue for a direct stimulatory effect of TGF $\alpha$ on the astrocytes through the activa- 
tion of its receptor, resulting in enhanced synthesis of intermediate gliofilaments and morphological rearrangements. In the transgenic mice, as in the normal CNS, the cellular source of TGF $\alpha$ may be either glial or neuronal (Ma et al., 1994b), both cell types expressing metallothionein 1 (Hidalgo et al., 1994). Ligand binding is known to trigger the intrinsic tyrosine kinase activity of the EGFR, leading to autophosphorylation of the receptor, the starting point of the signal transduction mechanism that mediates TGF $\alpha$ action (Carpenter and Cohen, 1990; Lee et al., 1995). Because EGFR activation can mobilize the Janus kinase/signal transducer and activator of transcription (STAT) signaling pathway (Ueno et al., 1997), a specific stimulatory effect of TGF $\alpha$ on the GFAP promoter via the STAT transcription factors may occur in a manner similar to that reported for the CNTF cytokine (Bonni et al., 1997). All astrocytes, regardless of their regional localization in the CNS, appear to be responsive to TGF $\alpha$ overproduction. This panspecific stimulatory effect of TGF $\alpha$ is in keeping with the observation that subsets of astrocytes in various areas of the CNS bear the EGFR (Gomez-Pinilla et al., 1988; Junier et al., 1994a; Ma et al., 1994c; Lisovoski et al., 1997; Sibilia et al., 1998) and are responsive in vitro to the differentiative actions of TGF $\alpha$ (Ma et al., 1994a, 1997; Miller et al., 1995; Faber-Elman et al., 1996; Mazzoni and Kenigsberg, 1997). These demonstrations of TGF $\alpha$ effects on cultured astrocytes, coupled with the observation of enhanced phosphorylated EGFR levels in the transgenic mice, make it highly unlikely that the astrocytic alterations observed in the MT1-hTGF $\alpha$ mice result from the insertion of the transgene in a genomic sequence involved in the control of astrocytic metabolism. The expression of TGF $\alpha$ in subsets of neurons and astrocytes in the adult CNS, and its upregulation during the course of astrogliosis observed in pathological situations ranging from a neurodegenerative process linked to a mutation (Junier et al., 1994a) to a focal electrolytic lesion (Junier et al., 1991), indicate that the growth factor should reach a threshold level for triggering astrogliosis. Once this threshold is attained, the continuous presence of TGF $\alpha$ would ensure the persistent astroglial reactivity. In the injured wild-type CNS, the time course of expression of TGF $\alpha$ and EGFR and the identity of their cellular sources are coherent with a role for the growth factor in the initiation, amplification, and maintenance of the astrogliosis process. For instance, either motoneuronal degeneration as in the wobbler mouse or motor nerve crush in wild-type mice trigger the appearance of TGF $\alpha$ in the injured motoneurons before the development of reactive astrocytes expressing EGFR and its ligand (Junier et al., 1994a; Lisovoski et al., 1997). At longer times, reactive astrocytes become the only source of the ligand and its receptor, indicating an autocrineparacrine mode of action for $\mathrm{TGF} \alpha$ during these late stages. When the CNS integrity is disrupted, as after a nerve cut, the appearance of TGF $\alpha$ and its receptor coincides with the full development of astrogliosis but does not precede it (Lisovoski et al., 1997). In this case, TGF $\alpha$ cannot be a primary inducer of astrogliosis but is likely to participate in the amplification of the initial signal and/or the maintenance of the reactive phenotype. Careful examination of astrogliotic characteristics induced by different types of lesions in mice lacking the TGF $\alpha$ gene could help dissect out the participation of the growth factor in each of these phases, although other EGFR ligands appear to compensate for the lack of TGF $\alpha$ in these transgenic mice (Luetteke et al., 1993; Mann et al., 1993).

\section{Conclusion}

In summary, the presence of astrocytes with reactive morphologies in several regions of the MT1-hTGF $\alpha$ CNS, coupled with the enhanced expression of GFAP and vimentin, demonstrates that overexpression of TGF $\alpha$ is sufficient to induce astrogliosis. Astrocytic reactivity appears to result from a direct effect of TGF $\alpha$ on the astrocytes through the activation of the EGF receptor. The lack of microglial reactivity singles out this factor before the cytokines, which affect both glial populations, and raises the interest in further explorations of the interactions between these polypeptides and TGF $\alpha$ after CNS injury. Altogether, the present results provide a role for this member of the EGF family in the adult CNS as an inducer of astrogliosis.

\section{REFERENCES}

Amaducci L, Forno KI, Eng LF (1981) Glial fibrillary acidic protein in cryogenic lesions of the rat brain. Neurosci Lett 21:27-32.

Andres-Barquin PJ, Fages C, Le Prince G, Rolland B, Tardy M (1994) Thyroid hormones influence the astroglial plasticity: changes in the expression of glial acidic fibrillary protein (GFAP) and of its encoding message. Neurochem Res 19:65-69.

Back SA, Colon M, Fallon JH, Meyskens Jr FL, Loughlin SE (1993) Ventral mesencephalic and cortical transplants into the rat striatum display enhanced activity for neutral endopeptidase 24.11. Brain Res 612:85-95.

Bignami A, Dahl D (1976) The astroglial response to stabbing. Immunofluorescence studies with antibodies to astrocyte-specific protein (GFAP) in mammalian and submammalian vertebrates. Neuropathol Appl Neurobiol 2:99-111.

Bonni A, Sun Y, Nadal-Vicens M, Bhatt A, Frank DA, Rozovsky I, Stahl N, Yancopoulos GD, Greenberg ME (1997) Regulation of gliogenesis in the central nervous system by the JAK-STAT signaling pathway. Science 278:477-482.

Burrows RC, Wancio D, Levitt P, Lilien L (1997) Response diversity and the timing of progenitor cell maturation are regulated by developmental changes in EGFR expression in the cortex. Neuron 19:251-267.

Carpenter G, Cohen S (1990) Epidermal growth factor. J Biol Chem 265:7709-7712.

Chiang CS, Stalder A, Samimi A, Campbell IL (1994) Reactive gliosis as a consequence of interleukin-6 expression in the brain: studies in transgenic mice. Dev Neurosci 16:212-221.

Clatterbuck RE, Price DL, Koliatsos VE (1996) Ciliary neurotrophic factor stimulates the expression of glial fibrillary acidic protein by brain astrocytes in vivo. J Comp Neurol 369:543-551.

Craig CG, Tropepe V, Morshead CM, Reynolds BA, Weiss S, van der Kooy D (1996) In vivo growth factor expansion of endogenous subependymal neural precursor cell populations in the adult mouse brain. J Neurosci 15:2649-2658.

Dahl D, Bignami A (1974) Heterogeneity of the glial fibrillary acidic protein in gliosed human brain. J Neurol Sci 23:551-563.

Danielsson PE, Forss-Peter S, Brow MA, Calavetta L, Milner RJ, Sutcliffe JG (1988) p1B15: a cDNA clone of the rat mRNA encoding cyclophilin. DNA 1:231-237.

Eddleston M, Mucke L (1993) Molecular profile of reactive astrocytesimplications for their role in neurological disease. Neuroscience 54:15-36.

Eng LF (1988) Regulation of glial intermediate filaments in astrogliosis. In: The biochemical pathology of astrocytes (Norenberg MD, Hertz L, Schousboe A, eds), pp 79-90. New York: Liss.

Faber-Elman A, Solomon A, Abraham JA, Marikovsky M, Schwartz M (1996) Involvement of wound-associated factors in rat brain astrocyte migratory response to axonal injury: in vitro stimulation. J Clin Invest 97:162-171.

Fallon JH, Annis CM, Gentry LE, Twardzik DR, Loughlin SE (1990) Localization of cells containing transforming growth factor- $\alpha$ precursor immunoreactivity in the basal ganglia of the adult rat brain. Growth Factors 2:241-250. 
Fattori E, Lazzaro D, Musiani P, Modesti A, Alonzi T, Ciliberto G (1995) IL-6 expression in neurons of transgenic mice causes reactive astrocytosis and increase in ramified microglial cells but no neuronal damage. Eur J Neurosci 7:2441-2449.

Ferrer I, Blanco R, Carulla M, Condom M, Alcantara S, Olive M, Planas A (1995) Transforming growth factor- $\alpha$ immunoreactivity in the developing and adult brain. Neuroscience 66:189-199.

Gomez-Pinilla F, Knauer DJ, Nieto-Sampedro M (1988) Epidermal Growth Factor receptor immunoreactivity in rat brain. Development and cellular localization. Brain Res 438:385-390.

Graeber MB, Streit WJ, Kreutzberg GW (1988) Axotomy of the rat facial nerve leads to the increased expression of CR3 complement receptor by activated microglial cells. J Neurosci Res 21:18-24.

Han VKM, Smith A, Myint W, Nygard K, Bradshaw S (1992) Mitogenic activity of epidermal growth factor on newborn rat astroglia: interaction with insulin-like growth factors. Endocrinology 131:1134-1142.

Heyser CJ, Masliah E, Samimi A, Campbell IL, Gold LH (1997) Progressive decline in avoidance learning paralleled by inflammatory neurodegeneration in transgenic mice expressing interleukin 6 in the brain. Proc Natl Acad Sci USA 94:1500-1505.

Hidalgo J, Garcia A, Oliva AM, Giralt M, Gasull T, Gonzalez B, Milnerowicz H, Wood A, Bremner I (1994) Effect of zinc, copper and glucocorticoids on metallothionein levels of cultured neurons and astrocytes from rat brain. Chem Biol Interact 93:197-219.

Jhappan C, Stahle C, Harkins RN, Fausto N, Smith GH, Merlino GT (1990) TGF $\alpha$ overexpression in transgenic mice induces liver neoplasia and abnormal development of the mammary gland and pancreas. Cell 61:1137-1146.

Junier MP, Ma YJ, Costa ME, Hoffman G, Hill DF, Ojeda SR (1991) Transforming growth factor $\alpha$ contributes to the mechanism by which hypothalamic injury induces precocious puberty. Proc Natl Acad Sci USA 88:9743-9747.

Junier MP, Hill DF, Costa ME, Felder S, Ojeda SR (1993) Hypothalamic lesions that induce female precocious puberty activate glial expression of the epidermal growth factor response gene: differential regulation of alternatively spliced transcripts. J Neurosci 13:703-713.

Junier MP, Coulpier M, Le Forestier N, Cadusseau J, Suzuki F, Peschanski M, Dreyfus PA (1994a) Transforming growth factor $\alpha$ (TGF $\alpha$ ) expression in degenerating motoneurons of the murine mutant wobbler: a neuronal signal for astrogliosis? J Neurosci 14:4206-4216.

Junier MP, Suzuki F, Onténiente B, Peschanski M (1994b) Neurotrophins and neurotrophin receptor gene expression associated with reactive gliosis in a neurodegenerative lesion of the rat brain. Mol Brain Res 24:247-260.

Kaser MR, Lakshmanan J, Fisher DA (1992) Comparison between epidermal growth factor, transforming growth factor- $\alpha$ and EGF receptor levels in regions of adult rat brain. Mol Brain Res 16:316-322.

Kimura H, Fischer WH, Schubert D (1990) Structure, expression and function of a schwannoma-derived growth factor. Nature 348:257-260.

Klein MA, Moller JC, Jones LL, Blethmann H, Kreutzberg GW, Raivich G (1997) Impaired neuroglial activation in interleukin-6 deficient mice. Glia 19:227-233.

Kornblum HI, Hussain RJ, Bronstein JM, Gall CM, Lee DC, Seroogy KB (1997) Prenatal ontogeny of the epidermal growth factor receptor and its ligand, transforming growth factor alpha, in the rat brain. J Comp Neurol 380:243-261.

Kudlow JE, Leung AWC, Kobrin MS, Paterson AJ, Asa SL (1989) Transforming growth factor- $\alpha$ in the mammalian brain. J Biol Chem 264:3880-3883.

Landis DMD (1994) The early reactions of non-neuronal cells to brain injury. Annu Rev Neurosci 17:133-151.

Lazar LM, Blum M (1992) Regional distribution and developmental expression of epidermal growth factor and transforming growth factor- $\alpha$ mRNA in mouse brain by a quantitative nuclease protection assay. J Neurosci 12:1688-1697.

Lee DC, Fenton SE, Berkowitz EA, Hissong MA (1995) Transforming growth factor alpha: expression, regulation, and biological activities. Pharmacol Rev 47:51-85.

Lewis SA, Balcarek JM, Krek V, Shelanski M, Cowan NJ (1984) Sequence of a cDNA clone encoding mouse glial fibrillary acidic protein: structural conservation of intermediate filaments. Proc Natl Acad Sci USA 81:2743-2746.
Lisovoski F, Blot S, Lacombe C, Bellier JP, Dreyfus PA, Junier MP (1997) Transforming growth factor $\alpha$ expression as a response of murine motoneurons to axonal injury and mutation-induced degeneration. J Neuropathol Exp Neurol 56:459-471.

Luetteke NC, Qiu TH, Peiffer RL, Smithies O, Lee DC (1993) TGF- $\alpha$ deficiency results in hair follicle and eye abnormalities in targeted and waved-1 mice. Cell 73:263-278

Ma YJ, Berg-von der Emde K, Moholt-Siebert M, Hill DF, Ojeda SR (1994a) Region-specific regulation of transforming growth factor $\alpha$ $(\mathrm{TGF} \alpha)$ gene expression in astrocytes of the neuroendocrine brain. J Neurosci 14:5644-5651.

Ma YJ, Dissen GA, Merlino G, Coquelin A, Ojeda SR (1994b) Overexpression of a human transforming growth factor- $\alpha$ (TGF- $\alpha$ ) transgene reveals a dual antagonistic role for TGF- $\alpha$ in female sexual development. Endocrinology 135:1392-1400.

Ma YJ, Hill DF, Junier MP, Costa ME, Felder SE, Ojeda SR (1994c) Expression of epidermal growth factor receptor changes in the hypothalamus during the onset of female puberty. Mol Cell Neurosci 5:246-262.

Ma YJ, Berg-von der Emde K, Rage F, Wetsel WC, Ojeda SR (1997) Hypothalamic astrocytes respond to transforming growth factor- $\alpha$ with the secretion of neuroactive substances that stimulate the release of luteinizing hormone-releasing hormone. Endocrinology 138:19-25.

Mann GB, Fowler KJ, Gabriel A, Nice EC, Williams RL, Dunn AR (1993) Mice with a null mutation of the TGF $\alpha$ gene have abnormal skin architecture, wavy hair, and curly whiskers and often develop corneal inflammation. Cell 73:249-261.

Marty S, Dusart I, Peschanski M (1991) Glial changes following an excitotoxic lesion in the CNS: I. Microglia/macrophages. Neuroscience 45:529-539.

Mazzoni IE, Kenigsberg RL (1997) Transforming growth factor- $\alpha$ 's effects on astroglial-cholinergic cell interactions in the medial septal area in vitro are mediated by $\alpha$ 2-macroglobulin. Neuroscience 81:1019-1030.

McLean IW, Nakane KP (1974) Periodate-lysine-paraformaldehyde fixative - a new fixative for immunoelectron microscopy. J Histochem Cytochem 22:1077-1083.

Miller S, Romano C, Cotman CW (1995) Growth factor upregulation of a phosphoinositide-coupled metabotropic glutamate receptor in cortical astrocytes. J Neurosci 15:6103-6109.

Nieto-Sampedro M, Gomez-Pinilla F, Knauer DJ, Broderick JT (1988) Epidermal growth factor receptor immunoreactivity in rat brain astrocytes. Response to injury. Neurosci Lett 91:276-282.

Norenberg MD (1994) Astrocyte response to CNS injury. J Neuropathol Exp Neurol 53:213-220.

Norton WT, Aquino DA, Hozuli I, Chiu FC, Brosnan CF (1992) Quantitative aspects of reactive gliosis: a review. Neurochem Res $17: 877-885$

Nowakowski RS, Lewin SB, Miller MW (1989) Bromodeoxyuridine immunohistochemical determination of the lengths of the cell cycle and the DNA-synthetic phase for an anatomically defined population. J Neurocytol 18:311-318.

Ojeda SR, Ma YJ, Rage F (1997) The transforming growth factor alpha gene family is involved in the neuroendocrine control of mammalian puberty. Mol Psychiatry 2:355-358.

Raivich G, Moreno-Flores MT, Moller JC, Kreutzberg GW (1994) Inhibition of posttraumatic microglial proliferation in a genetic model of macrophage colony-stimulating factor deficiency in the mouse. Eur J Neurosci 6:1615-1618.

Reier PJ (1986) Gliosis following CNS injury: the anatomy of astrocytic scars and their influences on axonal elongation. In: Astrocytes (Federoff S, Vernadakis I, eds), Vol 3, pp 263-324. New York: Academic.

Reynolds BA, Tetzalff W, Weiss S (1992) A multipotent EGFresponsive striatal embryonic progenitor cell produces neurons and astrocytes. J Neurosci 12:4565-4574.

Ridet JL, Malhotra SK, Privat A, Gage FH (1997) Reactive astrocytes: cellular and molecular cues to biological function. Trends Neurosci 20:570-577.

Rudge JS, Li Y, Pasnikowski EM, Mattsson K, Pan L, Yancopoulos GD, Wiegand SJ, Lindsay RM, Ip N (1994) Neurotrophic factor receptors and their signal transduction capabilities in rat astrocytes. Eur J Neurosci 6:693-705.

Seroogy KB, Lundgren KH, Lee DC, Guthrie KM, Gall CM (1993) 
Cellular localization of transforming growth factor- $\alpha$ mRNA in rat forebrain. J Neurochem 60:1777-1782.

Sibilia M, Steinbach JP, Stingl L, Aguzzi A, Wagner EF (1998) A strainindependent postnatal neurodegeneration in mice lacking the EGF receptor. EMBO J 17:719-731.

Smart TG, Xie X, Krishek BJ (1994) Modulations of inhibitory and excitatory amino-acid receptor ion channels by zinc. Prog Neurobiol 42:393-441.

Smith ME, Eng LF (1988) The development of the gliotic plaque in experimental allergic encephalomyelitis. In: Neurology and neurobiology, Vol 48, pp 291-300. New York: Liss.

Tropepe V, Craig CG, Morshead CM, van der Kooy D (1997) Transforming growth factor- $\alpha$ null and senescent mice show decreased neural progenitor cell proliferation in the forebrain subependyrma. J Neurosci 17:7850-7859.
Ueno H, Sasaki K, Miyagawa K, Honda H, Mitani K, Yazaki Y, Hirai H (1997) Antisense repression of proto-oncogene c-Cbl enhances activation of the JAK-STAT pathway but not the Ras pathway in epidermal growth factor receptor signaling. J Biol Chem 272:8739-8743.

Weickert CS, Blum M (1995) Striatal TGF- $\alpha$ : postnatal developmental expression and evidence for a role in the proliferation of subependymal cells. Dev Brain Res 86:203-216.

Wilcox JN, Derynck R (1988) Localization of cells synthesizing transforming growth factor- $\alpha$ mRNA in the mouse brain. $\mathrm{J}$ Neurosci 8:1901-1904.

Winter CG, Saotome Y, Levison SW, Hirsh D (1995) A role for ciliary neurotrophic factor as an inducer of reactive gliosis, the glial response to central nervous system injury. Proc Natl Acad Sci USA 92:5865-5869. 